\title{
Presence of Mycotoxins in Feed and Dairy Products of Cattle in Paraná, Brazil
}

\author{
Rodrigo Barros Navarro \\ Médico Veterinário, Capal Cooperativa Agroindustrial, Arapoti, Paraná. \\ E-mail: rodrigo@capal.coop.br
}

Rodrigo de Almeida

Universidade Federal do Paraná, Departamento de Zootecnia, Programa de Pós-Graduação em Zootecnia. E-mail: ralmeida@ufpr.br

\section{Magali Soares dos Santos Pozza}

${ }^{3}$ Universidade Estadual de Maringá (UEM), Programa de Pós-Graduação em Zootecnia (PPZ).E-mail: pozzamagali@yahoo.com.br

\section{Ferenc Istvan Bánkuti}

${ }^{3}$ Universidade Estadual de Maringá (UEM), Programa de Pós-Graduação em Zootecnia (PPZ).E-mail: ferencistvan@gmail.com

\section{Camila Brandão Celeste Ferreira Itavo}

${ }^{4}$ Universidade Federal do Mato Grosso do Sul (UFMS), Programa de Pós-Graduação em Ciência Animal (PPGCA). E-mail: camila.itavo@ufms.br

\section{Cibele Scheneeberger}

Universidade Estadual de Londrina (UEL), Departamento de Medicina Veterinária Preventiva. E-mail: cibele.sch@gmail.com

Alexandre Menezes Dias

Universidade Federal do Mato Grosso do Sul (UFMS), Programa de Pós-Graduação em Ciência Animal (PPGCA). E-mail: alexandre.menezes@ufms.br 
Ana Carolina Vital

Universidade Estadual de Maringá (UEM), Programa de Pós-Graduação em Zootecnia (PPZ).

E-mail: ana_carolv@hotmail.com

Geraldo Tadeu Dos Santos (Corresponding Author)

National Institute of Science and Technology of Dairy Production Chain (INCT-LEITE/UEL), UEM-PPZ and UFMS-PPGCA. Brazil, 5790 Colombo Avenue, Maringá, Paraná, Brazil. E-mail: gtsantos50@gmail.com

Received: Feb. 3, 2020

doi:10.5296/jas.v8i3.16856
Accepted: Mar. 11, $2020 \quad$ Published: Apr. 15, 2020

URL: https://doi.org/10.5296/jas.v8i3.16856

\begin{abstract}
Milk contamination by mycotoxins is considered a public health problem. Therefore, the objective of this study was to identify these contaminants in concentrates and in the milk from 31 high-producing herds. Only two of the 55 concentrate samples analyzed showed the presence of aflatoxin $\mathrm{G}_{1}\left(\mathrm{AFG}_{1}, 3.2\right.$ and $\left.3.6 \mu \mathrm{g} \cdot \mathrm{kg}^{-1}\right)$. AFM1 was detected in $93.5 \%$ of the 62 milk samples analyzed with a range from 0.045 to $0.442 \mu \mathrm{g} \cdot \mathrm{L}^{-1}$. All of the $\mathrm{AFM}_{1}$ concentrations were below the maximum limit tolerated $\left(0.5 \mu \mathrm{g} \cdot \mathrm{kg}^{-1}\right)$ by the Brazilian Agência Nacional de Vigilância Sanitária (ANVISA). There was no difference in $\mathrm{AFM}_{1}$ contamination levels for both sampling periods (summer and winter). In conclusion, the $\mathrm{AFM}_{1}$ contamination in animal feed and, consequently, in milk is within the limits tolerated by ANVISA for Brazil $\left(\leq 0.5 \mu \mathrm{g} \cdot \mathrm{kg}^{-1}\right)$. Furthermore, no season effect on $\mathrm{AFM}_{1}$ levels was found.
\end{abstract}

Keywords: aflatoxins, contaminants, dairy farming, food security

\title{
1. Introduction
}

Dairy demand has grown more than the population growth in Brazil, and it is estimated that by 2025 the production will be at least 47.5 million tons of milk to supply a population of 219 million people (Vilela et al., 2017). In addition, there are concerns about the milk quality and its safety. Some risks associated with this product may be prevented or controlled by appropriate procedures related to food storage to avoid the appearance of fungi and the use of inorganic mycotoxin adsorbents in feed management.

The Normative Instructions of MAPA, No. 76 (IN-76) (BRASIL, 2018a) and the Normative Instruction of MAPA, No. 77 (IN-77) (BRASIL, 2018b) establish the identity and quality standards of pasteurized and raw refrigerated milk, and controls residues that are concern to public health. The contamination of milk with aflatoxin $\mathrm{M}_{1}\left(\mathrm{AFM}_{1}\right)$ is a consequence of poor 
handling practices (ANVISA, 2011).

The season of the year affects the prevalence of mycotoxins in food, and hot and humid climates are known to favor the growth of aflatoxin-producing fungi. However, contradictory data have verified the seasonal effect of the presence of mycotoxins in feeds (El Marnissi et al., 2012; Diaz and Espitia, 2006).

The highest food $\mathrm{AFB}_{1}$ contamination in the winter may be due to its storage under unsatisfactory conditions (Flores-Flores et al., 2015). It is also worth mentioning that the co-occurrence of more than one mycotoxin in the same food because fungi can produce several mycotoxins, which may affect their toxicity, shows an additive and even a synergistic effect (Gelderblom et al., 2002).

The objective of this study was to identify the levels of mycotoxin contaminants in concentrate animal feeds and in the milk. The effect of the milk collection season (summer and winter) on the levels of contamination by $\mathrm{AFM}_{1}$ was also evaluated.

\section{Materials and Methods}

Milk and feed samples were collected from 31 dairy farms adopting an intensive production system in Paraná State, Southern Brazil. The evaluated animal feeds for lactating cows were corn silage, oats and rye, haylages, commercial concentrates, soybean meal, whole cottonseed, corn meal, and dried citrus pulp.

This study was conducted in two distinct periods: from June to July (winter season) and January to February (summer season). Four milk samples were collected from each farm, packaged in an isothermal environment with recyclable ice, and then frozen at $-20{ }^{\circ} \mathrm{C}$ in a freezer until all the analysis were completed.

Concentrate samples were collected during the same period and similarly stored for mycotoxin analysis $\left(\mathrm{AFB}_{1}, \mathrm{AFB}_{2}, \mathrm{AFG}_{1}, \mathrm{AFG}_{2}\right.$, and ochratoxin $\mathrm{A}$ ) at the Veterinary Toxicology Laboratory from the Londrina State University as well as milk samples from each farm. Milk samples were also subjected to serum extraction to determine $\mathrm{AFM}_{1}$ using Spectrometry and Chromatography Laboratory from Maringá State University.

For the detection of mycotoxins ( $\mathrm{AFB}_{1}, \mathrm{AFB}_{2}, \mathrm{AFG}_{1}, \mathrm{AFG}_{2}$, and ochratoxin $\mathrm{A}$ ) was used the thin layer chromatography described by Soares and Rodriguez-Amaya (1989). The following concentrations (mg/mL) were used $\mathrm{AFB}_{1}$ (2.55), $\mathrm{AFB}_{2}$ (2.62), $\mathrm{AFG}_{1}$ (2.45), $\mathrm{AFG}_{2}$ (4.55), and ochratoxin A (143.05) (Sigma-Aldrich Inc., USA), according to the AOAC methodology (AOAC, 2003). The detection limits of the method were 2 and $5 \mu \mathrm{g} \cdot \mathrm{kg}^{-1}$ and the limits of determination were 4 and $10 \mu \mathrm{g} \cdot \mathrm{kg}^{-1}$ for aflatoxin and ochratoxin, respectively.

The milk samples were analyzed in duplicate using the Ridascreen ${ }^{\circledR}$ Fast AFM $_{1}$ immunoenzymatic kit (R-Biopharm ${ }^{\circledR}$. This system comprises a "well" support coated with anti-IgG, five standard AFM 1 solutions $\left(0,0.25,0.5,1\right.$, and $\left.2 \mu \mathrm{g} \cdot \mathrm{kg}^{-1}\right)$ containing anti-AFM 1 polyclonal IgG, conjugated, chromogen, and blocking solution according to the protocol described in the manual. 


\section{Mll Macrothink}

The reading was performed using a spectrophotometer at a wavelength $(\lambda)$ of $450 \mathrm{~nm}$ and the results were expressed as the average of the observed values for each duplicate. Absorbances were calculated for each observation according to:

$\mathrm{A}=$ absorbance at $\lambda$ of $450 \mathrm{~nm}$

A0ppt $=$ absorbance of standard $0\left(0 \mu \mathrm{g} \cdot \mathrm{kg}^{-1}\right.$ of $\left.\mathrm{AFM}_{1}\right)$

$\mathrm{A}_{\mathrm{i}}=$ observed absorbance of each sample (from $i$ to $n$ ).

The absorbance values (\%) of each observation were converted to concentration $\left(\mu \mathrm{g} \cdot \mathrm{kg}^{-1}\right)$ based on the standard curve parameterized for each test provided by the Softmax-Pro® software, version 5.4. The analysis protocol was for competitive immunoaffinity assays [enzyme-linked immunosorbent assay (ELISA)] read at the endpoint of each reaction based on the protocol for melamine (Softmax-Pro v.5.4).

The data were statistically analyzed using the MIXED procedure of the Statistical Analysis System (SAS version 9.3) according to the following model:

$Y_{i k}=\mu+t_{i}+e_{i k}$

$\mathrm{Y}_{\mathrm{ik}}=$ observed value

$\mu=$ overall mean

$\mathrm{t}_{\mathrm{i}}=$ treatment effect $(\mathrm{i}=\mathrm{C} 1$ and $\mathrm{C} 2)$

$\mathrm{e}_{\mathrm{ik}}=$ residual error

\section{Results}

$\mathrm{AFB}_{1}, \mathrm{AFB}_{2}, \mathrm{AFG}_{2}$, and $\mathrm{OCRA}$ were not detected in all 22 samples of commercial concentrates analyzed. Only two samples showed $\mathrm{AFG}_{1}$ both with low levels of contamination (3.2 and $3.6 \mu \mathrm{g} \cdot \mathrm{kg}-1$, Table 1$)$.

The results of the analysis of mycotoxins in samples of soybean meal, cottonseed, citrus pulp, corn meal, wheat bran, and brewers grains showed no aflatoxins $\left(\mathrm{AFB}_{1}, \mathrm{AFB}_{2}, \mathrm{AFG}_{1}\right.$, and $\mathrm{AFG}_{2}$ ) and ochratoxins (Table 1).

Table 1. Analysis of aflatoxins $\mathrm{B}_{1}\left(\mathrm{AFB}_{1}\right), \mathrm{AFB}_{2}, \mathrm{AFG}_{1}, \mathrm{AFG}_{2}$ and $\mathrm{OCRA}$ in dairy farm ingredients from Paraná - Brazil

\begin{tabular}{lcccccc}
\hline \multicolumn{7}{c}{ Aflatoxins $\left(\mu \mathrm{g} \cdot \mathrm{kg}^{-1}\right)$} \\
\hline Feed & No. of samples & $\mathrm{AFB}_{1}$ & $\mathrm{AFB}_{2}$ & $\mathrm{AFG}_{1}$ & $\mathrm{AFG}_{2}$ & $\mathrm{OCRA}$ \\
\hline Commercial & 22 & nd & nd & $3.4^{*}$ & nd & nd \\
concentrates & 14 & nd & nd & nd & nd & nd \\
Soybean meal & 6 & nd & nd & nd & nd & nd \\
Whole cottonseed & 5 & nd & nd & nd & nd & nd \\
Corn meal & 5 & nd & nd & nd & nd & nd \\
Citrus pulp & 1 & nd & nd & nd & nd & nd \\
Wheat bran & 2 & nd & nd & nd & nd & nd \\
Brewers grains & & & & & & \\
\hline
\end{tabular}


* Mean of two positive samples: 3.2 and $3.6 \mu \mathrm{g} \cdot \mathrm{kg}^{-1}$

Table 2 shows that the productivity of the farms varied from 17.5 to $34.6 \mathrm{~kg} \cdot \mathrm{cow}^{-1} \cdot \mathrm{day}^{-1}$ and the occurrence of $\mathrm{AFM}_{1}$ in two distinct collection periods $\left(\mathrm{PC}_{1}-\right.$ summer and $\mathrm{PC}_{2}-$ winter).

Table 2. Productivity data and aflatoxin $\mathrm{M}_{1}\left(\mathrm{AFM}_{1}\right)$ in cow's milk, values of two collection periods (Summer and Winter)

\begin{tabular}{|c|c|c|c|c|c|}
\hline \multirow[b]{2}{*}{ Farms } & \multirow{2}{*}{$\begin{array}{c}\text { Productivity } \\
\left(\mathrm{kg} \cdot \mathrm{cow}^{-1} \cdot\right. \\
\left.\text { day }^{-1}\right)\end{array}$} & \multicolumn{2}{|c|}{ Aflatoxin $\mathrm{M}_{1}\left(\mu \mathrm{g} \cdot \mathrm{L}^{-1}\right)$} & \multirow{2}{*}{\multicolumn{2}{|c|}{ Mean $\pm \mathrm{SD}^{*}$}} \\
\hline & & $\begin{array}{c}\text { Summer } \\
\left(\mathrm{C}_{1}\right)\end{array}$ & $\begin{array}{c}\text { Winter } \\
\left(\mathrm{C}_{2}\right)\end{array}$ & & \\
\hline 1 & 30.0 & 0.153 & 0.092 & 0.123 & \pm 0.043 \\
\hline 2 & 22.8 & 0.217 & 0.092 & 0.155 & \pm 0.088 \\
\hline 3 & 32.3 & 0.070 & 0.099 & 0.085 & \pm 0.020 \\
\hline 4 & 33.0 & 0.001 & 0.419 & 0.210 & \pm 0.001 \\
\hline 5 & 28.1 & 0.195 & 0.222 & 0.209 & \pm 0.019 \\
\hline 6 & 32.9 & 0.405 & 0.094 & 0.249 & \pm 0.220 \\
\hline 7 & 28.6 & 0.169 & 0.091 & 0.130 & \pm 0.055 \\
\hline 8 & 29.0 & 0.372 & 0.082 & 0.227 & \pm 0.205 \\
\hline 9 & 32.1 & 0.093 & 0.093 & 0.093 & \pm 0.000 \\
\hline 10 & 17.5 & 0.001 & 0.294 & 0.148 & \pm 0.001 \\
\hline 11 & 22.8 & 0.357 & 0.045 & 0.201 & \pm 0.221 \\
\hline 12 & 29.1 & 0.246 & 0.091 & 0.169 & \pm 0.110 \\
\hline 13 & 26.3 & 0.277 & 0.383 & 0.330 & \pm 0.075 \\
\hline 14 & 32.2 & 0.377 & 0.045 & 0.211 & \pm 0.235 \\
\hline 15 & 29.0 & 0.309 & 0.295 & 0.302 & \pm 0.010 \\
\hline 16 & 29.1 & 0.131 & 0.283 & 0.207 & \pm 0.107 \\
\hline 17 & 30.5 & 0.000 & 0.308 & 0.155 & \pm 0.001 \\
\hline 18 & 31.0 & 0.092 & 0.093 & 0.093 & \pm 0.001 \\
\hline 19 & 26.7 & 0.169 & 0.093 & 0.131 & \pm 0.054 \\
\hline 20 & 27.1 & 0.204 & 0.280 & 0.242 & \pm 0.054 \\
\hline 21 & 19.2 & 0.189 & 0.166 & 0.177 & \pm 0.016 \\
\hline 22 & 28.8 & 0.257 & 0.442 & 0.349 & \pm 0.131 \\
\hline 23 & 22.3 & 0.253 & 0.068 & 0.160 & \pm 0.131 \\
\hline 24 & 24.9 & 0.232 & 0.308 & 0.270 & \pm 0.053 \\
\hline 25 & 34.6 & 0.143 & 0.092 & 0.118 & \pm 0.036 \\
\hline 26 & 30.1 & 0.217 & 0.238 & 0.227 & \pm 0.014 \\
\hline 27 & 25.1 & 0.001 & 0.175 & 0.088 & \pm 0.001 \\
\hline 28 & 27.0 & 0.189 & 0.093 & 0.141 & \pm 0.067 \\
\hline 29 & 30.0 & 0.255 & 0.093 & 0.174 & \pm 0.115 \\
\hline 30 & 32.6 & 0.288 & 0.092 & 0.190 & \pm 0.139 \\
\hline 31 & 28.1 & 0.180 & 0.181 & 0.180 & \pm 0.001 \\
\hline \multirow[t]{2}{*}{ Mean } & DP & $\mathrm{AFM}_{1} \mathrm{C} 1$ & $\mathrm{AFM}_{1} \mathrm{C} 2$ & P-value & \\
\hline & 28.15 & 0.195 & 0.176 & 0.7927 & \\
\hline
\end{tabular}

$\mathrm{SD}=$ standard deviation of milk production in $\mathrm{kg}$

Collection Periods (C)

$\mathrm{C} 1=$ Summer - Collection in January and February 
$\mathrm{C} 2=$ Winter - Collection in June and July

* Mean \pm standard deviation of two collection periods (C1 and $\mathrm{C} 2)$.

Figure 1 shows the AFM1 values of the two sampling periods ( $\mathrm{C} 1$ and $\mathrm{C} 2)$, and the maximum limit tolerated for aflatoxin in Brazil.

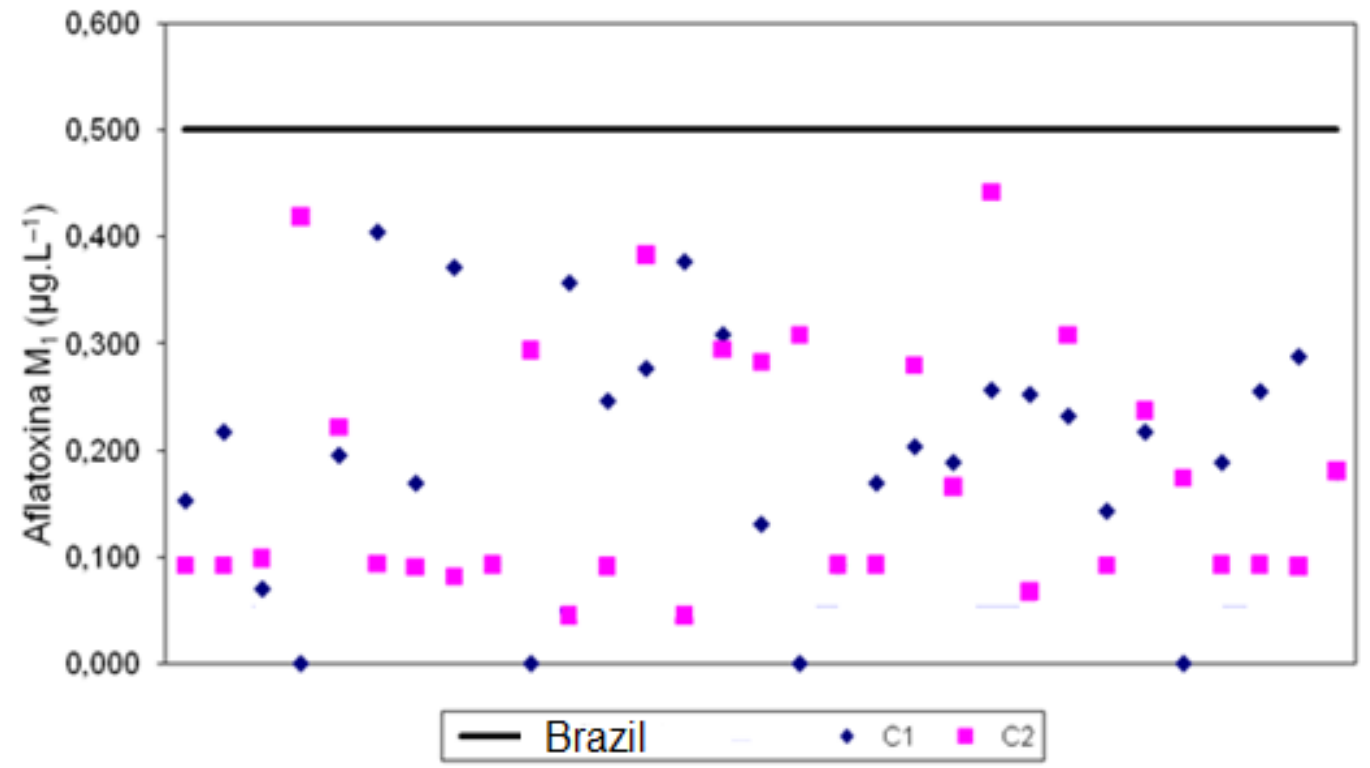

Figure 1. Distribution of aflatoxin $\mathrm{M}_{1}$ values and the maximum limit tolerated for Brazil - $\mathrm{C}_{1}$ - summer and $\mathrm{C}_{2}$ - winter

\section{Discussion}

In contrast to the results observed in this work, some studies showed concerning levels of aflatoxin contamination (Sassahara et al., 2003; 2005). Sassahara et al. (2003) reported AFB1 contamination in $13.6 \%$ of 272 samples initially produced to feed dairy cattle in Paraná. In another study, the presence of $\mathrm{AFB}_{1}$ was detected in $7(25 \%)$ of the 27 commercial feed samples analyzed in Northern Paraná (Sassahara et al., 2005). Oliveira et al. (2010) verified $\mathrm{AFB}_{1}$ contamination in $40 \%$ of animal feed concentrates, obtaining levels between 1.0 and $19.5 \mu \mathrm{g} \cdot \mathrm{kg}^{-1}$. Pontes Neto et al. (2002) evaluated feed samples supplied to dairy cows in the Northern region of Paraná and found that $31.08 \%$ were contaminated with aflatoxins. Furthermore, Motta et al. (2015) analyzed 288 total mixed samples (forage plus concentrate) and verified the occurrence of $\mathrm{AFB}_{1}$ in $31.44 \%$ with contents between 1.68 and 194.51 $\mu \mathrm{g} \cdot \mathrm{kg}^{-1}$.

The results of the analysis of five mycotoxins in samples of soybean meal, cottonseed, citrus pulp, corn meal, wheat bran, and brewer's grains showed no aflatoxins ( $\mathrm{AFB}_{1}, \mathrm{AFB}_{2}, \mathrm{AFG}_{1}$ and $\mathrm{AFG}_{2}$ ) and ochratoxins (Table 1).

Globally, mycotoxins in animal feeds are serious threats to the health of humans and animals. A higher incidence of contaminated dairy cow feeds in other countries was also observed by Xiong et al. (2018) in China, who evaluated 174 samples (corn, wheat bran, soybean meal, 
peanut meal, and cottonseed) and found that $35.1 \%$ were positive for $\mathrm{AFB}_{1}$.

Granados-Chinchilla et al. (2017) evaluated 970 feed samples for animals in Costa Rica and detected a $24 \%$ rate of aflatoxin contamination. Diehrius et al. (2008) analyzed 169 feed samples from 24 dairy farms for contamination by 20 mycotoxins found a high prevalence of deoxynivalenol, zearalenone, roquefortina $\mathrm{C}$, and mycophenolic acid. In the present study, milk samples were collected on farms that produced between 800 and 10,000 L of milk day ${ }^{-1}$, and we observed detectable levels of $\mathrm{AFM}_{1}$, which were below the maximum limit tolerated by ANVISA (ANVISA, 2011).

We observed that from 62 samples analyzed, 93.5\% showed detectable levels of AFM 1 ranging from 0.001 to $0.442 \mu \mathrm{g} \cdot \mathrm{L}^{-1}$ but below the maximum limit allowed by ANVISA (2011). Sabino et al. (1989) found $18 \%$ of positive samples at levels of 0.10 to $1.68 \mu \mathrm{g} \cdot \mathrm{L}^{-1}$. For some samples, the limit established by ANVISA is $\leq 0.5 \mu \mathrm{g} . \mathrm{L}^{-1}$. Sassahara et al. (2005) observed $\mathrm{AFM}_{1}$ levels of 0.29 to $1.97 \mu \mathrm{g} \cdot \mathrm{L}^{-1}$ in $24 \%$ of raw milk samples collected from farms in the State of Paraná, and only three (7\%) were above the limit of $0.5 \mu \mathrm{g} \cdot \mathrm{L}^{-1}$. Shundo and Sabino (2006) analyzed 107 milk samples, and 79 (73.8\%) showed AFM levels varying between 0.02 and $0.26 \mu \mathrm{g} . \mathrm{L}^{-1}$. Of these 107 samples, 22, 42, and 43 were raw, ultra-high temperature (UHT) and pasteurized milk samples, of which 13, 34, and 32, respectively, showed some $\mathrm{AFM}_{1}$ contamination.

Several studies have demonstrated a seasonal trend in milk contamination by $\mathrm{AFM}_{1}$, and usually higher incidence occurs during winter when the animals are fed with more concentrates than during other seasons (Patterson et al., 1980; Galvano et al., 1986; Kamkar, 2005; Diaz and Espitia, 2006). The effect of the climactic season on contamination by mycotoxins was also studied by Fallah et al. (2016) who reported contradictory results. Seasonal variations were not observed in this study probably because these herds do not change their feed management around the year, because the supply of concentrates to the animals remains constant.

Many countries have legislation to control the maximum contamination limit of exported dairy products, and that of $\mathrm{AFM}_{1}$ is $0.5 \mu \mathrm{g}$. $\mathrm{L}^{-1}$. This demonstrates that $100 \%$ of the analyzed milk samples would be approved based on this parameter relating to $\mathrm{AFM}_{1}$ for dairy export to these countries. Milk processing, whether by pasteurization or UHT, does not destroy AFM 1 and has a cumulative effect on the body and, therefore, care must be taken to maximally reduce the level of $\mathrm{AFM}_{1}$ in milk. Similarly with our study and sampling milk samples in the spring and summer months, Oliveira et al. (2010) obtained only one sample with a level $>0.5$ $\mu \mathrm{g} \cdot \mathrm{L}^{-1}$. However, $20 \%$ of the samples showed $\mathrm{AFM}_{1}$ levels higher than the TUL of the European Union legislation $\left(0.05 \mu \mathrm{g} \cdot \mathrm{L}^{-1}\right)$. Gonçalez et al. (2005) found 17 contaminated samples from the 43 analyzed, and $11(64.7 \%)$ of them showed concentrations above the maximum limit allowed by Brazilian legislation.

Establishing the importance of the Brazilian dairy sector in the international market will require producers, industries, research institutions, and government leaders to be aware of the need for sustainability. 


\section{Conclusion}

In conclusion, no $\mathrm{AFB}_{1}, \mathrm{AFB}_{2}$, and $\mathrm{AFG}_{2}$ contamination was detected in the feed produced for animal consumption and only two concentrate samples presented low $\mathrm{AFG}_{1}$ values. The milk samples analyzed for AFM 1 were all within the limit tolerated by Brazilian legislation, which is $\leq 0.5 \mu \mathrm{g} \cdot \mathrm{kg}^{-1}$. There were no differences in the $\mathrm{AFM}_{1}$ contamination levels between the two sampling periods (summer and winter).

\section{Conflict of interest statement}

The authors declare that they have no conflict of interest.

\section{Acknowledgments}

The present study was funded by "Conselho Nacional de Desenvolvimento Científico e Tecnológico" (CNPq) in Brasilia, DF, Brazil, Projeto Universal 2016, Processo no. 405689/2016-0 and "Instituto Nacional de Ciência e Tecnologia para a Cadeia Produtiva do Leite" (INCT-LEITE/UEL-PR), Londrina, Paraná, Brasil”, and "Fundação Araucaria", Curitiba-Paraná and Programa de Pós-graduação em Zootecnia (PPZ) - UEM.

\section{References}

ANVISA (2011). AGÊNCIA NACIONAL DE VIGILÂNCIA SANITÁRIA. Resolução RDC no 07. Anvisa estabelece limites para presença de micotoxinas em alimentos. In: http://portal.anvisa.gov.br/documents/10181/2968262/RDC_07_2011_COMP.pdf/afe3f054-b c99-4e27-85c4-780b92e2b966. Acessado: em 23/05/2018.

AOAC (2003). Official Methods of Analysis of AOAC International. 17 ${ }^{\text {ed }}$ Gaithersburg: AOAC International. $141 \mathrm{p}$.

BRASIL (2018a). Ministério da Agricultura, Pecuária e Abastecimento. Instrução Normativa $n^{o} 76$, de 30 de novembro de 2018. Dispõe sobre regulamentos técnicos de produção, identidade, qualidade, coleta e transporte de leite. Edição 230, Seção 1, página 9 do Diário Oficial da União, Brasília (DF), 26 Nov. (2018), 6p. Google Scholar.

BRASIL (2018b). Ministério da Agricultura, Pecuária e Abastecimento. Instrução Normativa $n^{\circ} 77$ de novembro de 2018. Brasília (DF): Diário Oficial da União (in Portuguese). Google Scholar.

Diaz, G. J., \& Espitia, E. (2006). Occurrence of aflatoxin $\mathrm{M}_{1}$ in retail milk samples from Bogota, Colombia. Food Additives \& Contaminants, 23, 811-815. https://doi.org/10.1080/02652030600681617

Driehuis, F., Spanjer, M. C., Scholten, J. M., \& Giffel, M. C. (2008). Occurrence of Mycotoxins in Feedstuffs of Dairy Cows and Estimation of Total Dietary Intakes. Journal of Dairy Science, 91, 4261-4271. https://doi.org/10.3168/jds.2008-1093

El Marnissi, B., Belkhou, R., Morgavi, D. P., Bennani, L., \& Boudra, H. (2012). Occurrence of aflatoxin $\mathrm{M}_{1}$ in raw milk collected from traditional dairies in Morocco. Food and Chemical Toxicology: An International Journal Published for the British Industrial 
Biological Research Association, 50, 2819e28. https://doi.org/10.1016/j.fct.2012.05.031

Fallah, A., Fazlollahi, R., \& Emami, A. (2016). Seasonal study of aflatoxin $M_{1}$ contamination in milk of four dairy species in Yazd, Iran. Food Control, 68, 77-82. https://doi.org/10.1016/j.foodcont.2016.03.018

Flores-Flores, M. E., Lizarraga, E., Cerain, A. L., \& Gonzalez-Penas, E. (2015). Presence of mycotoxins in animal milk: A review. Food Control, 53, 163-176. https://doi.org/10.1016/j.foodcont.2015.01.020

Galvano, F., Galofaro, V., \& Galvano, G. (1996). Occurrence and stability of aflatoxin $\mathrm{M}_{1}$ in Milk and milk products: a worldwide review. Journal of Food Protection, 59, 1079-1090. https://doi.org/10.4315/0362-028X-59.10.1079

Gelderblom, W. C., Marasas, W. F., Lebepe-Mazur, S., Swanevelder, S., Vessey, C. J., \& Hall P. de, L. (2002). Interaction of fumonisin B (1) and aflatoxin B(1) in a shortterm carcinogenesis model in rat liver. Toxicology, 171, 161-173. https://doi.org/10.1016/S0300-483X(01)00573-X

Gonçalez, E., Felicio, J. D., Pinto, M. M., Rossi, M. H., Nogueira, J. H. C., \& Manginelli, S. (2005). Ocorrência de aflatoxina $\mathrm{M}_{1}$ em leite comercializado em alguns municípios do Estado de São Paulo. Arquivos do Instituto Biológico, 72, 435-438.

Granados-Chinchilla, G., Molina, A., Chavarría, G., Alfaro-Cascante, M., \& Murillo-Williams, A. (2017). Aflatoxins occurrence through the food chain in Costa Rica: Applying tho one Health approach to mycotoxin surveillance. Food Control, 82, 217-226. https://doi.org/10.1016/j.foodcont.2017.06.023

Kamkar, A. (2005). A study on the occurrence of aflatoxin M1 in raw milk produced in Sarab city of Iran. Food Control, 16, 593-599. https://doi.org/10.1016/j.foodcont.2004.06.021

Motta, T. P., Frizzarin, A., Martins, T., Miranda, M., Arcaro, J. M. P., Ambrosio, L. A., \& Pozza, C. R. (2015). Estudo sobre a ocorrência de fungos e aflatoxina B 1 na dieta de bovinos leiteiros em São Paulo. Pesquisa Veterinária Brasileira, 35, 23-28. https://doi.org/10.1590/S0100-736X2015000100006

Oliveira, C. A. F., Sebastião, L. S., Fagundes, H., Rosim, R. E., \& Fernandes, A. M. (2010). Determinação de aflatoxina B1 em rações e aflatoxinas $\mathrm{M}_{1}$ no leite de propriedades do estado de São Paulo. Ciência e Tecnologia de Alimentos, 30(Supl.1), 221-225. https://doi.org/10.1590/S0101-20612010000500034

Patterson, D. S. P., Glancy, E. M., \& Roberts, B. A. (1980). The "carry over" of aflatoxin M1 into the Milk of cows fed rations containing a low concentration of aflatoxin $\mathrm{B}_{1}$. Food Cosmetic Toxicology, 18, 35-37. https://doi.org/10.1016/0015-6264(80)90008-5

Pontes Netto, D., Zanluchi, A. T., Sassahara, M., \& Yanaka, E. K. (2002) Micotoxinas em alimentação animal no período de maio/1997 a março/2001 no Laboratório de Toxicologia Veterinária da Universidade Estadual de Londrina - Londrina - PR. SEMINA: Ciências Agrárias, 23, 63-69. https://doi.org/10.5433/1679-0359.2002v23n1p63 


\section{Macrothink}

Journal of Agricultural Studies

ISSN 2166-0379

2020, Vol. 8, No. 3

Sabino, M., Purchio, A., \& Zorzetto, A. P. (1989). Variations in the level of aflatoxinin cows milk consumed in the city of São Paulo, Brazil. Food Additives and Contaminants, 6, 321-361. https://doi.org/10.1080/02652038909373786

Sassahara, M., Pontes Netto, D. P., \& Yanaka, E. K. (2005). Aflatoxin occurrence in foodstuff supplied to dairy cattle and aflatoxin $\mathrm{M}_{1}$ in raw milk in the north of Paraná state. Food Chemical Toxicology, 43, 981-984. https://doi.org/10.1016/j.fct.2005.02.003

Sassahara, M., Yanaka, E. K., \& Pontes Netto, D. P. (2003). Ocorrência de aflatoxina e zearalenona em alimentos destinados ao gado leiteiro na região Norte do Estado do Paraná. Semina. Ciências Agrárias, 24, 63-72. https://doi.org/10.5433/1679-0359.2003v24n1p63

Shundo, L., \& Sabino, M. (2006). Aflatoxin $\mathrm{M}_{1}$ in milk by immunoaffinity column cleanup with TLC/HPLC determination. Brazilian Journal of Microbiology, 37, 164-167. https://doi.org/10.1590/S1517-83822006000200013

Soares, L. M. V., \& Rodriguez-Amaya, D. B. (1989). Survey of aflatoxins, ochratoxin A, zearalenone and sterigmatocystin in some Brazilian foods by using multi-toxin thinlayer chromatographic method. Journal of Association of Official Analytical Chemists International, 72, 22-26. https://doi.org/10.1093/jaoac/72.1.22

Vilela, D., Resende, J. C., Leite, J. B., \& Alves, B. (2017). A evolução do leite no Brasil em cinco décadas. Revista de Política Agrícola, XXVI, 5-24.

Xiong, J., Xing, L., Zhou, H., Liu, Y., \& Wu, L. (2018). Occurrence of aflatoxin B1 in dairy cow feedstuff and aflatoxin $\mathrm{M}_{1}$ in UHT and pasteurized milk in central China. Food Control, 9, 386-390. https://doi.org/10.1016/j.foodcont.2018.05.022

\section{Copyright Disclaimer}

Copyright for this article is retained by the author(s), with first publication rights granted to the journal.

This is an open-access article distributed under the terms and conditions of the Creative Commons Attribution license (http://creativecommons.org/licenses/by/4.0/). 